\title{
Room Loan Information System Website Based Using PHP And MYSQL With Waterfall Model
}

\author{
1Doni Oktaviana, ${ }^{2}$ Mustofa Abi Hamid* \\ Email : ${ }^{1}$ oktavianadoni@gmail.com, 2abi.mustofa@untirta.ac.id* \\ *: coresponding author \\ 1,2Department of Electrical Engineering Vocational Education, Universitas Sultan Ageng Tirtayasa
}

Article history

Received July 7, 2021

Revised Okt 5, 2021

Accepted Nov 30, 2021

Keywords

Information system

PHP

MySQL

Alpha Testing

Beta Testing
Research by developing an information system is a research that aims to produce and develop an information service system design in the form of website-based rooms lending using PHP as a programming language and MySQL as a database that will be used at the Faculty of Teacher Training and Education, Sultan Ageng Tirtayasa University in room management as room loan, room loan schedule, room loan data, and room information. This study uses the waterfall development model, with 5 (five) stages of development including the stages of communication, planning, modeling, construction and deployment. In this research using Alpha and Beta testing to 3 (three) media experts and 31 (thirty one) users including 1 (one) admin and 30 (thirty) students. Data collection techniques using interview techniques, observation and dissemination of research instruments. With data analysis in the form of a feasibility test using a Likert scale instrument of 4 (four) assessment scores to media experts and respondents. The final product produced is a website for a rooms loaning information system, by average score by media experts (Alpha Testing) of 71.6 with the "very feasible" category. The results of the feasibility test by users (Beta Testing) were 34.32 with the "very feasible" category. Therefore, it can be concluded that the website-based room loan information system is very feasible to use

This is an open access article under the CC-BY-SA license.

\section{Introduction}

The development of information systems cannot be separated from technological advances as the implementation of the development of a website-based room loan information system. Researchers developed a website-based room loan information system aimed at facilitating the management of room loans and providing information on the room loan schedule. A websitebased room loan information system developed by researchers using PHP-based programming with a MySQL database used in the Teaching and Education Faculty of Sultan Ageng Tirtayasa University. 
In research (Trenggono, 2014) the information system was made based on the problem that the filing in the recording of loans made was still classified as conventional or manual. So the researchers developed a web-based lending information system to facilitate lending activities. Existing research (Wahyuni, Fauziah, \& Mardiani, 2020) that the development model carried out on a website-based room loan information system is the Rapid Application Development model with the problem of borrowers not getting a loan schedule so that the loan process is hampered. Research on information service systems was also carried out by (Kantami, M. F., Fauziah, \& Nathasia, N. D., 2020) with the application design method using the RAD (Rapid Application Development) method. with the stages of making an application using PHP and MySQL. (Brianorman \& Octariadi, 2017) the information system that has been developed has the aim of facilitating the process of room management with the problem of time inefficiency in room management so that the researchers designed a computerized room use information system. Research conducted by (Herlambang, A. D., Rachmadi, A., Rahmatika, A. P., DwiUtami, D. I., \& Hapsari, S. W. (2020) V- Model for Meeting Room Management Information System Development. An organization needs good meeting room booking management that could be accessed in real-time. Convenient access for meeting room information will make searching activities for the meeting room availability in an organization easier. Research (Imron, M., Sutikno, G. R., \& Dazki, I. N. (2020) on the Implementation of Push Notification in Website-Based Facilities and Infrastructure Loan System, This research was conducted in an effort to assist activities carried out by Amikom University Purwokerto students by providing facilities and infrastructure that can support activities such as projectors, laptops, laboratory equipment and room class With the application of Push Notification technology or Messaging server.

According to observations regarding room borrowing at the Faculty of Teacher Training and Education, Sultan Ageng Tirtayasa University, information was obtained that data collection and filing for room borrowing on campus was still done conventionally or manually by collecting archives of room loan letters and it was difficult for borrowers to obtain information on borrowing schedules and room conditions. So far, it is not known how the quality of room loan management is to improve room management. Therefore, researchers are interested in submitting research on room loan information systems at the Faculty of Teacher Training and Education, Sultan Ageng Tirtayasa University.

\section{Method}

This research was conducted at the Faculty of Teacher Training and Education Untirta, with the research method used is R\&D (Research and Development) and the development model used is the waterfall development model. According to (Sugiyono, 2019) research that focuses on a particular product result and tests the level of effectiveness of the product is called R\&D research or Research and Development. Meanwhile, according to (Pressman, 2010) waterfall is an old 
model and in its use this model has been widely used, especially for software engineering. The waterfall model used has 5 (five) stages of research, namely the stages of communication, planning, modeling, construction and deployment. The communication stage aims to analyze existing problems with the solutions provided, the planning stage is the preparation stage in product development, the modeling stage is the stage of illustrating the software by making a design, at the construction stage the process of forming and testing an information system that has been made based on a representative model appropriate flow and display, and the last stage of dissemination of the information system implementation stage widely to users by providing an explanation of the product flow that will be run

In testing the feasibility of the information system by means of alpha testing to 3 media experts, and beta testing to 30 student respondents and 1 room manager. Data collection instruments for development needs can be done by doing at each stage of the waterfall development model on Figure 1:

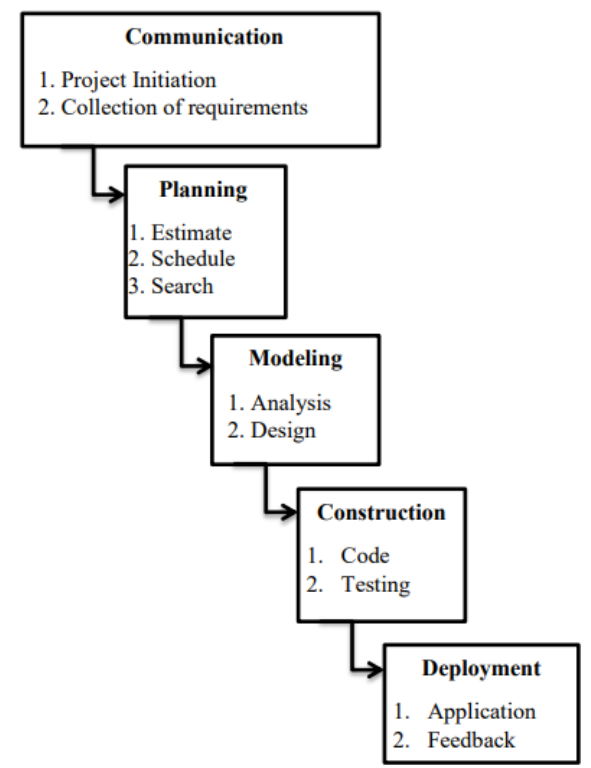

Figure 1. waterfall development model

The data analysis technique used in this research is instrument validity test and product feasibility analysis with alpha testing and beta testing. The instrument validity test is an assessment of the alpha and beta testing instruments to find valid instrument data before being used in testing. After the alpha and beta testing instruments are said to be valid, then alpha and beta testing can be carried out to analyze the feasibility of a website-based room loan information system. The data obtained from alpha and beta testing using a Likert scale of 4 assessment scores then converts the test assessment to test the feasibility of the product with the following conditions. 
Table 1. likert scale category

\begin{tabular}{cc}
\hline Category & Score \\
\hline Strongly agree & 4 \\
Agree & 3 \\
Disagree & 2 \\
Strongly Disagree & 1 \\
\hline
\end{tabular}

Scores from media experts and users were analyzed by calculating the average answer based on the score of each assessment calculated by the following formula:

$$
\mathrm{X}=\left(\sum \mathrm{x}\right) / \mathrm{n}
$$

The results of the data obtained are then presented in accordance with the eligibility test criteria according to (Mardapi, 2017) as shown in Table 2.

Table 2. Eligibility based on rating scale

\begin{tabular}{ccc}
\hline No & Category & Eligibility category \\
\hline 1 & $\mathrm{x} \geq \bar{x}+1 . S B x$ & Very Worthy \\
2 & $\bar{x}+1 . S B x>\mathrm{x} \geq \bar{x}$ & Worth \\
3 & $\bar{x}>\mathrm{x} \geq \bar{x}-1 . S B x$ & Not Feasible \\
4 & $\mathrm{x}<\bar{x}-1 . S B x$ & Very Unworthy \\
\hline
\end{tabular}

Information:

$\mathrm{x}=$ Average user overall score

$\mathrm{SBx}=$ Standard deviation of user's overall score

$\mathrm{x}=$ Score achieved

If the scores from media experts and users are obtained, then the next step is to look for the feasibility of the product with the average score used to interpret the feasibility of the product in accordance with the provisions of the eligibility category.

\section{Result and Discussion}

In the process of developing a website-based room loan information system by carrying out research stages, including the stages of communication, planning, modeling, structure or coding, and testing. At the communication stage, activities are carried out to find information data through interviews and observations to find what is needed from various problem factors by analyzing needs. Based on the results of interviews and observations that the system applied is still conventional. The planning stage is to prepare the needs needed in designing a room loan website. In this stage, the researcher collects the components to develop a room loan information system including system requirements planning, hardware planning, and software planning.

Then the modeling stage is the design stage of a website-based lending information system by developing a design through UML or Unfield Modeling Language which includes Use case diagrams, Activity diagrams, Sequence Diagrams, and class diagrams, as well as designing website display designs and preparing database designs for data management. and information collected. 
The next stage of construction is the stage to create software by entering program codes into the code editor in accordance with the design modeling and databases that are needed and tested. In the process of developing the implementation of the coding structure of the website-based room loan information system using the sublime text 3 code editor.

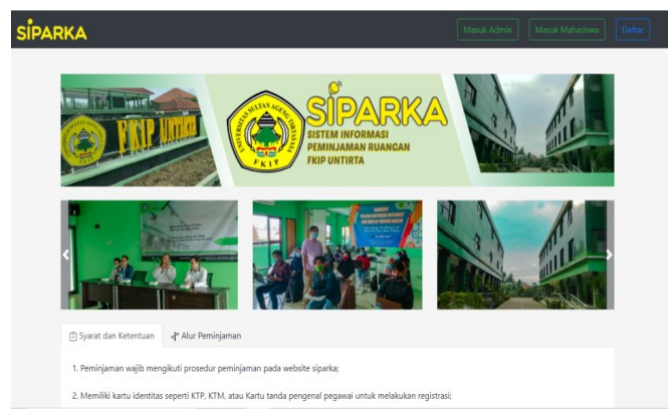

Figure 2. Main page view

On the main page of the website there is the SIPARKA logo, login button for admin and students, register button to become a new member, website banner, information on terms and conditions, and loan flow. On the student website page there are several main menus, namely a list of borrowing schedules or student dashboards to display the name of the room that is being borrowed, the student profile in it displays student personal data, borrowing in which there is a history of rooms that have been borrowed by the user, and room info as room detail information. On the admin website page, the function is to manage the number of rooms that are being borrowed, manage room loans.

At this stage of testing is carried out to determine the success of the product developed by assessing the product. At the testing stage, it has several testing steps including testing aspects of functionality, aspects of efficiency, aspects of portability, alpha and beta testing.

1. Testing the functionality aspect

Functionality testing using Acunetix Vulnerability Web Scanner Software, which functions to detect vulnerabilities, bugs and loopholes by detecting the entire website.

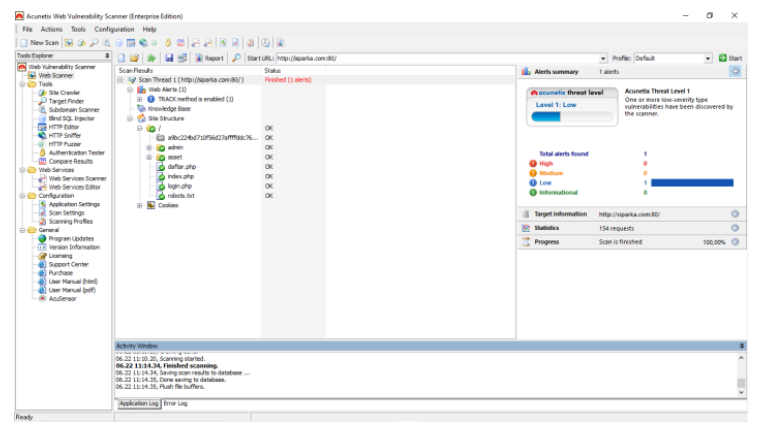

Figure 3. Functional aspect test results

Based on the test results with the Acunetix Vulnerability Web Scanner, level 1 (Low) results were obtained, which means the website is safe and can be used from error vulnerabilities. 
2. Testing aspects of efficiency

At the efficiency testing stage, the website is tested using the GTMetrix website tool which functions to detect website speed.

Table 3.Efficiency aspect test results

\begin{tabular}{cccccc}
\hline No & Web page & $\begin{array}{c}\text { Page Load } \\
\text { (Seconds) }\end{array}$ & $\begin{array}{c}\text { Page Size } \\
\text { (KB) }\end{array}$ & $\begin{array}{c}\text { Speed } \\
\text { Contentful Paint } \\
\text { (Seconds) }\end{array}$ & GTmetrix Grade \\
\hline 1 & Main page & 2.5 & 1010 & 0.9 & $\mathrm{~B}(83 \%)$ \\
2 & Register page & 2.5 & 352 & 1.4 & $\mathrm{~B}(84 \%)$ \\
3 & Login Page & 2.5 & 351 & 1.4 & $\mathrm{~B}(85 \%)$ \\
4 & Admin Page & 2.6 & 352 & 1.5 & $\mathrm{~B}(82 \%)$ \\
5 & Student Page & 2.6 & 352 & 1.5 & $\mathrm{~B}(83 \%)$ \\
\hline & Average & 2.54 & 483.4 & 1.34 & $\mathrm{~B}(83.4 \%)$ \\
\hline
\end{tabular}

So the results from GTmetrix on page load have an average speed of loading each website page which is 2.54 seconds, on the page size or the size of each website page the largest is the main page $1010 \mathrm{~KB}$ because the main page contains many images and the average size of each website page $483.4 \mathrm{~KB}$, while the average content display speed is 1.34 Seconds, and the average website performance Grade is $83.4 \%$ with a B value, it can be said that the website is good to use, so it can be concluded that the website has good efficiency to meet the efficiency aspect.

3. Testing the portability aspect

In the portability testing stage, the website is tested using the help of a website browser which functions to test websites with different web browsers.

Table 4. Portability aspect test results

\begin{tabular}{llcccc}
\hline No & Web Browser & Version & $\begin{array}{c}\text { Operating } \\
\text { system }\end{array}$ & Information & Criteria \\
\hline 1 & Google Chrome & 91 & Windows 10 & No error & Get away \\
2 & Mozila Firefox & 89 & Windows 10 & No error & Get away \\
3 & Internet Explorer & 31 & Windows 10 & No error & Get away \\
4 & Opera & 87 & Windows 7 & No error & Get away \\
5 & Google chrome (Mobile) & 88 & Android 10 & No error & Get away \\
\hline
\end{tabular}

In testing the portability aspect, it can be concluded that the room loan information system website can run smoothly on various desktop or mobile web browsers such as Google Chrome, Mozilla Firefox, Internet Explorer, Opera, Google chrome (Mobile Browser). So it can be said that the website has a level of flexibility and fulfills a good portability aspect.

4. Alpha and beta testing

a. Alpha testing 
From the results of alpha testing, data obtained from testing by 3 (three) media experts include assessment data on website interface creativity indicators, media effectiveness, feature implementation, and information data implementation.

Table 5. Media Expert's assessment result

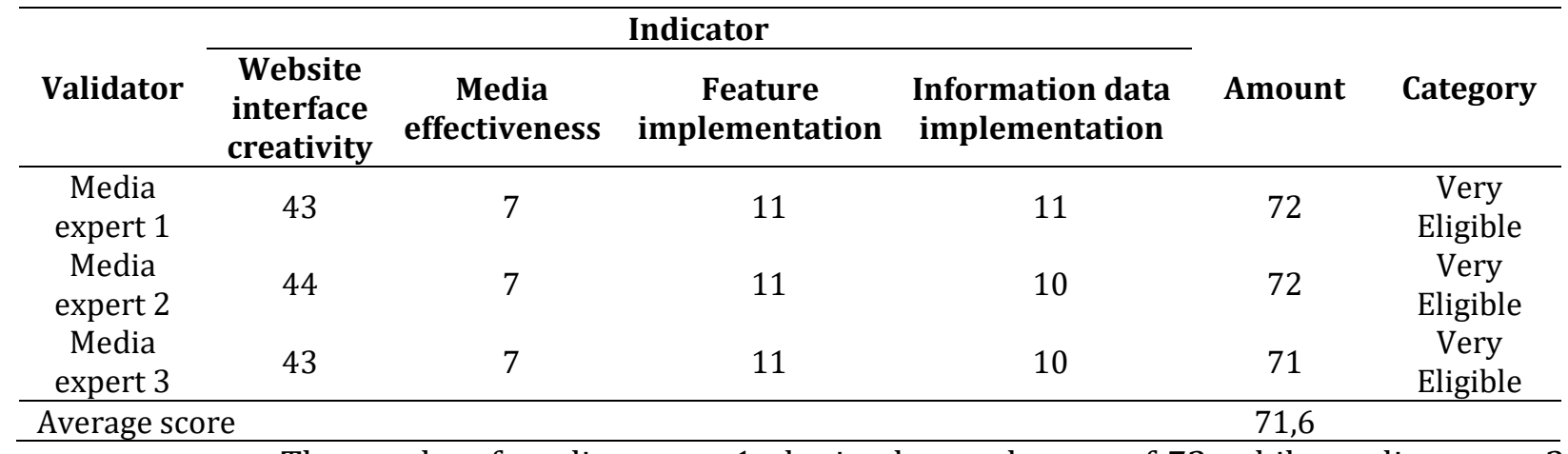

The results of media expert 1 obtained a total score of 72 , while media expert 2 obtained a total score of 72, and for media expert 3 obtained a total score of 71 . Based on the assessments of the three media experts, the average score was 71.6 with a vulnerable score of x 60 so that it can be categorized as "Very Eligible" to be used as a room loan information system. This is in line with research (Irwanto, 2021) which has a value of $75 \%$ which means it is very feasible to use.

b. Beta testing

From the results of the average score of the feasibility test assessment by 31 respondents including 30 students as room users and 1 FKIP UNTIRTA staff as room manager (admin).

Table 6. Beta Test Results

\begin{tabular}{cc}
\hline Avarage score & Category \\
\hline 34,32 & Very Eligible \\
\hline
\end{tabular}

The results of the average score of the feasibility test assessment by 31 respondents including 30 students as room users and 1 FKIP UNTIRTA staff as room manager (admin) that is getting an average value of 34.32 means that the provision of vulnerable scores obtained from the data in Table 18 is $\times 30$, then the result becomes 34.3230 this shows that the room loan information system that has been studied can be categorized as "Very Eligible".

And lastly, the results of the website deployment stage are hosting to provide broad access to use and get feedback at the information system dissemination stage having positive responses by users related to the website that has been explained and tested in a system and appearance. So the response from website users must be used directly with a certain time. 


\section{Conclusion}

The development of this web-based room loan information system uses the Research and Development (RnD) development method by formulating a development model with a waterfall model consisting of 5 stages, namely the communication, planning, modeling, construction, and deployment stages. The process in developing a room loan information system includes making designs such as use case diagrams, class diagrams, activity diagrams, sequence diagrams and designing interface designs. Furthermore, the design of the information process and database design using the XAMPP webserver with MySQL for data storage. In the process of making the interface display on the information system using sublime text 3 software with the PHP programming language in the process of editing the system code. And the results of the feasibility test found by media experts (Alpha Testing) showed an average value of 71.6 which could be said to be "Very Eligible", while the results of the feasibility test by users (Beta Testing) showed an average value of 34.32 which could be said "Very Eligible" so that from the results of this feasibility test assessment the room loan information system can be used as a room loan information management system at the Faculty of Teacher Training and Education, Sultan Ageng Tirtayasa University.

\section{References}

Brianorman, Y., \& Octariadi, B. C. (2017). Perancangan Sistem Pengelolaan Ruang Berbasis Web Di Universitas Muhammadiyah Pontianak. Cybernetics, 131-138.

Herlambang, A. D., Rachmadi, A., Rahmatika, A. P., DwiUtami, D. I., \& Hapsari, S. W. (2020). VModel Untuk Pengembangan Sistem Informasi Manajemen Ruang Rapat. Jurnal Teknologi Informasi dan Ilmu Komputer (JTIIK), 313-322.

Imron, M., Sutikno, G. R., \& Dazki, I. N. (2020). Implementasi Push Notification Pada Sistem Peminjaman Sarana dan Prasarana Berbasis Website. Informatika, 174-182.

Irwanto. (2021). Perancangan Sistem Informasi Sekolah Kejuruan dengan Menggunakan Metode Waterfall (Studi kasus SMK PGRI 1 Kota Serang-Banten). Jurnal Pendidikan, 86-107.

Kantami, M. F., Fauziah, \& Nathasia, N. D. (2020). Room Loan Information System At WebsiteBased National University. Jurnal Mantik, 374-382.

Mardapi, D. (2017). Pengukuran, Penilaian dan Evaluasi Pendidikan. Yogyakarta: Parama Publishing.

Pressman, R. S. (2010). Software Engineering: A Practitioner's Approach, Seventh Edition. New York: McGraw-Hill.

Sugiyono. (2019). Metode Penelitian Pendidikan (Pendekatan Kuantitaif, Kualitatif, dan $R$ \& D. Bandung: Alfabeta. 
Trenggono, D. H. (2014). Sistem Peminjaman Berbasis Web Sebagai Media Layanan Di Studio Multimedia SMK 2 Sewon. Yogyakarta: Universitas Negeri Yogyakarta .

Wahyuni, U. R., Fauziah, \& Mardiani, E. (2020). Web-Based Room Loan Management Services Using Web Based RAD. Jurnal Mantik, 452-459. 